\title{
PERAN ANGGOTA DPD RI PROVINSI DKI JAKARTA PERIODE 2014-2019 DALAM MENYERAP ASPIRASI WARGA DKI JAKARTA
}

\author{
Agus Salman ${ }^{1}$ Efriza $^{2}$ \\ ${ }^{1}$ Mahasiswa Pasca Sarjana Ilmu Politik Universitas Nasional \\ 2Dosen Ilmu Pemerintahan Universitas Sutomo \\ 1email:salmoncidodol@gmail.com
}

Paper Accepted: 25 Desember 2021 Paper Reviewed: 01-06 Januari 2022 Paper Edited: 07-13 Januari 2022 Paper Approved: 15 Januari 2022

\begin{abstract}
ABSTRAK
Peran Anggota Dewan Perwakilan Daerah (DPD RI) sebagai representasi suara daerah sangatlah diharapkan agar tercapainya sebuah check and balance dalam hubungan pusat dan daerah, begitu pula dengan daerah Provinsi DKI Jakarta dengan segala permasalahannya. Sebagai Ibukota Negara, DKI Jakarta menyimpan masalah-masalah yang harus segera ditangani agar menjadi sebuah suara daerah secara menyeluruh untuk disuarakan dalam level nasional. Namun ternyata, Peran Anggota DPD dari Provinsi DKI Jakarta Periode 2014-2019 dalam menyerap dan memperjuangkan aspirasi warga DKI Jakarta yang sangat heterogen dalam parlemen seakan tak terdengar atau tersosialisasikan dengan baik. Sementara, DPD dengan kewenangan yang terbatas seakan menjadi sebuah keterbatasan dalam bertindak sebagai penyerap aspirasi maupun merumuskan dalam proses legislasi yang memihak kepentingan aspirasi daerah.
\end{abstract}

Kata kunci: Peran, Aspirasi, DPD, DKI Jakarta

\section{PENDAHULUAN}

\section{Latar Belakang}

Perkembangan reformasi di Indonesia di bidang ketatanegaraan membawa pada perubahan penting yang salah satunya memunculkan lembaga negara baru yang bernama DPD. Sejak dilakukannya Amandemen UndangUndang Dasar (UUD) 1945, maka sistem parlemen Indonesia telah berubah dari sistem unikameral ke sistem bikameral. Manifestasi dari lembaga ini telah terbangun harapan masyarakat daerah bahwa permasalahan daerah dapat diperjuangkan di tingkat nasional.

Amandemen konstitusi lalu, adalah jalan utama untuk memperkuat posisi lembaga ini sebagai lembaga legislatif untuk mendampingi DPR. Kehadiran DPD didasari perlunya ada lembaga negara yang dapat menjembatani kepentingan pusat dan daerah. DPD telah membangkitkan senafas dengan semangat otonomi daerah suatu harapan masyarakat di daerah bahwa kepentingan daerah dan masalah-masalah yang dihadapi daerah dapat diangkat dan diperjuangkan di tingkat nasional. Diharapkan juga bahwa kebijakan-kebijakan publik di tingkat nasional maupun daerah tidak merugikan dan bahkan berpihak kepada kepentingan daerah dan kepentingan rakyat di seluruh tanah air (Efriza, 2014). Secara regulasi kali pertama, berdasarkan turunan konstitusi bahwa keberadaan DPD tercantum dalam Undang-Undang Nomor 22 Tahun 2003 tentang Susunan dan 
Kedudukan (Susduk) Majelis

Permusyawaratan Rakyat (MPR), Dewan Perwakilan Rakyat (DPR), DPD dan Dewan Perwakilan Rakyat Daerah (DPRD). Namun jarang disebutkan bahwa tugas, fungsi dan wewenang DPD menurut Undang-Undang (UU) Nomor 22 Tahun 2003, seakan DPD hanyalah subordinat DPR.

Munculnya ide kamar kedua bertumpu pada keinginan memberi ruang "checks and balances" serta saling mengisi secara kreatif antara dua lembaga parlemen. Sepintas ingin sejalan dengan model perwakilan sistem dua kamar murni (strong bicameralism) seperti di Amerika dengan "House of Representative" (DPR) dan Senat atau Dewan Negara dan Dewan Rakyat di Malaysia. Jika itu yang diterapkan, DPD memiliki hak legislasi, pengawasan dan anggaran yang cukup bertenaga sebagai counterpart DPR (M. Ichsan Loulembah, 2016: 139).

Nyatanya, keberadaaan DPD seperti "kerakap tumbuh di batu," dilahirkan tapi seolah tidak dikehendaki, DPD hadir dengan ketidakberdayaannya. Kehadirannya seolah diterima setengah hati. Ini adalah realitas yang harus diterima negeri ini bahwa adanya lembaga seperti Senator namun lemah dan menyedihkan berbagai kalangan. Biaya memilih dan dipilih anggota DPD sangat besar, namun fungsinya baru menjadi "pelengkap penyerta" di lembaga legislatif kita, hingga telah memasuki periode ketiga lembaga tersebut, (Syafuan Rozi dan Efriza, 2010: 229). Jika struktur politik seperti ini masih dipertahankan, maka masa depan DPD sebagai penyeimbang DPR dalam sistem bikameral tentu saja mengkhawatirkan. Di saat kinerja DPR kurang maksimal maka bandul demokrasi pun akan bergerak ke titik yang pesimis, posisi DPD seakan terlupakan. DPR dan DPD semestinya memiliki kewenangan, fungsi dan hak yang setara, agar kelemahan DPR tersebut bisa ditutupi oleh masifnya kinerja DPD.

DPD diharapkan menjadi salah satu kamar dari sistem parlemen dua kamar dalam format baru perwakilan politik Indonesia. DPD adalah parlemen yang mewakili wilayah atau daerah dalam hal ini provinsi. Tetapi, struktur ini tidak sepenuhnya mencerminkan sistem bikameral. DPD yang semestinya salah satu kamar dari sistem dua kamar, tidak mempunyai kekuasaan yang memadai. Kewenangan DPD hanya terbatas pada kekuasaan-kekuasaan yang berkaitan dengan otonomi daerah, hubungan pusat dan daerah, pembentukan dan pemekaran serta penggabungan daerah, pengelolaan sumber daya alam dan sumber ekonomi lainnya, serta masalah perimbangan keuangan Pusat dan Daerah (Pasal 22 Undang-Undang Dasar 1945). Diluar itu, kekuasaan DPD hanya memberi pertimbangan kepada DPR. Dengan demikian, keberadaan DPD relatif tidak berfungsi.

Meskipun merupakan representasi daerah-daerah yang telah dipilih langsung oleh rakyat, namun keberadaan DPD dapat diibaratkan antara "ada dan tiada". Betapa tidak, karena fungsi dan wewenang yang dimiliki oleh DPD hanya terbatas tidak seperti yang dimiliki oleh DPR. Dampak lainnya adalah, tidak terjadinya checks and balances antara DPR dan DPD itu sendiri. Padahal, kelahiran DPD sangat didasari oleh keinginan semua pihak termasuk pemerintah pusat dan daerah untuk memperbaiki hubungan kerja dan penyaluran kepentingan antara kedua level pemerintahan tersebut. Dalam hal ini, DPD juga diharapkan hadir sebagai lembaga yang mampu membantu untuk mengatasi kesenjangan antara pusat dan daerah sesuai semangat otonomi daerah yang menjamin keadilan, demokrasi, dan jaminan keutuhan integritas wilayah negara.

Pada dasarnya DPD sengaja didesain hampir atau memang hendak menyerupai DPR. Sebagaimana diatur dalam UndangUndang Dasar 1945 Amandemen bahwa DPD merupakan representasi langsung rakyat di daerah yang menjadi konstituten perwakilannya. Tugas dan tanggung jawab DPD berkisar pada pengawasan dan pengusulan realisasi hubungan pusat dan daerah berserta kepentingan yang ada di dalamnya ke dalam produk perundangundangan. Dalam hal ini, sebenarnya peran DPD sangat strategis, karena dengan begitu pemerintah pusat 
sebenarnya mempunyai rekan kerja yang seimbang dalam hal penyelenggaraan hubungan pemerintah pusat dan daerah.

Ide pembentukan DPD dalam kerangka sistem legislatif Indonesia memang tidak terlepas dari ide pembentukan struktur dua kamar parlemen atau bikameral. Dengan struktur bikameral itu diharapkan proses legislasi dapat diselenggarkan dengan sistem double check yang memungkinkan representasi seluruh rakyat secara relatif dapat disalurkan dengan basis sosial yang lebih luas.

Peran dan kedudukan DPD yang strategis tersebut, diharapkan bahwa pembentukan DPD sebagai salah satu institusi negara yang baru adalah dalam rangka memberikan kesempatan kepada orang-orang daerah untuk ikut mengambil kebijakan dalam tingkat nasional, khususnya yang terkait dengan kepentingan daerah. Pembentukan ini diharapkan akan lebih memperkuat integrasi nasional serta semakin menguatnya perasaan kebersamaan sebagai sebuah bangsa yang terdiri dari daerah-daerah (Efriza dan Syafuan Rozi, 2010).

Secara sederhana, berdasarkan Pasal 22D UUD 1945 perubahan ketiga, dapat dikatakan bahwa peran dan kewenangan DPD hanya sebatas pengusulan Rancangan Undang-Undang (RUU) yang terkait dengan otonomi daerah, pengawasan khusus untuk bidang otonomi daerah, serta turut serta dalam pembahasan RUU yang terkait dengan otonomi daerah namun hanya ketika RUU tersebut sebelum dibahas bersama oleh DPR dan Pemerintah atau hanya sampai pada rapat pembahasan tingkat I di DPR.

Harapan lain dari kemunculan DPD, terlepas dari kuat atau lemahnya fungsi yang diembannya, adalah kontribusinya dalam menstimulasi secara positif kemajuan demokrasi di Indonesia, terutama keterwakilan suara daerah dalam kebijakan yang berpihak pada warga negara, yang lebih banyak berada di daerah. Namun dalam perkembangannya, setumpuk harapan yang disematkan kepada para "senator" kita ini tak bisa mewujud karena terbentur oleh ragam aturan yang diciptakan oleh anggota lembaga perwakilan dari partai politik, yang tentu saja tak akan merelakan kewenangannya diambil begitu saja oleh para wakil rakyat dari non-partai ini. Meski dibentuk lembaganya, namun dikebiri kewenangan dan fungsinya. Itulah nasib lembaga DPD kita hari ini.

Dengan merefleksikan posisi DPD saat ini, maka lembaga perwakilan baru yang diperkenalkan Undang-Undang Dasar 1945 (UUD 1945) hasil perubahan itu adalah sebuah format kompromi yang hampir-hampir tercerabut dari akar paradigma teoritiknya. Karenanya, lembaga perwakilan kita ini tidak bisa disebut menganut sistem bikameral sama sekali, dalam pengertian weak bicameralism apalagi strong bikameralism, andaipun ingin dipaksakan penyebutan umumnya adalah sistem soft bikameral (Reni Dwi Purnomowati, 2005).

Peran DPD sangat minimal, padahal prosedur pemilihan anggotanya justru sangat rumit dan sulit. Seseorang baru dapat menjadi anggota DPD apabila ia benar-benar tokoh yang dikenal luas di daerahnya dan ia bukan orang partai, sehingga benar-benar dapat dikenal di luar konteks mesin politik yang bernama partai politik. Tetapi, setelah terpilih menjadi anggota DPD, lalu harus hidup di Jakarta, tugasnya hanya memberi pertimbangan kepada DPR dalam urusan-urusan legislasi. Kewenangan DPD yang sangat terbatas ini terasa unsur diskriminatifnya, apalagi kalau dikaitkan dengan tingginya ekspektasi masyarakat untuk berpartisipasi secara luas dan kompetitif dalam kehidupan ketatanegaraan di Indonesia.

Banyak yang berharap agar pandangan dan harapan masyarakat Indonesia tetap dapat memberikan dampak konstruktif yang besar melalui DPD. Meski begitu, keberadaan DPD sebagai representasi daerah, seakan masih dipandang sebelah mata dan belum tersosialisasi secara menyeluruh, seperti kerapkali muncul pertanyaan siapakah anggota DPD dari daerahnya, ketika pemilu pun kerap muncul pertanyaan anggota DPD dari partai apa, dimana DPD berkantor, dan lain sebagainya. 
Dalam format legislator DPD bahwa setiap Provinsi diwakili oleh empat orang untuk DPD, sehingga total keseluruhan dari 33 Provinsi berjumlah 132 orang (https://jakarta.dpd.go.id/public/post/de tail/dpd-ri). DKI Jakarta memiliki perwakilan empat calon anggota legislatif (caleg) terpilih untuk DPD. Keempat anggota DPD dari Provinsi DKI Jakarta untuk Periode 2014-2019 adalah Fahira Fahmi Idris, S.E, M.H dengan perolehan suara 511.323 suara; Drs. H. A.M. Fatwa (475.601 suara); DR. Dailami Firdaus, S.H, LL.M, MBA (416.929 suara); dan DR. Abdul Azis Khafia, S.Si, M.Si (368.397 suara). Dalam perkembangannya, pada tanggal 14 Desember 2017, Drs. H. A.M. Fatwa meninggal dunia, lalu digantikan oleh Sabam Sirait yang dilantik pada tanggal 15 Januari 2018, sebagai PAW (Penggantian Antar Waktu) dengan perolehan suara kelima sebesar 237.273 suara.

DKI Jakarta adalah Ibukota Negara Indonesia dan merupakan kota terbesar di Indonesia, idealnya para anggota DPD dari provinsi DKI Jakarta dapat lebih memaksimalkan peran dan fungsinya sebagai anggota DPD dalam memperjuangkan kepentingan daerah DKI Jakarta dan masalah-masalah yang dihadapi untuk diangkat dan diperjuangkan ke tingkat nasional. Dalam menjalankan peran dan fungsinya untuk memperjuangkan kepentingan warga Jakarta dan masalah-masalah yang dihadapi, diperlukan peran dari anggota DPD untuk menyerap aspirasi warga DKI Jakarta. Anggota DPD dari Provinsi DKI Jakarta dapat melaksanakan kegiatan menyerap aspirasi, menghimpun, menampung dan menindaklanjuti aspirasi daerah, meski tetap adanya faktor yang mendukung dan menghambat dalam penyerapan aspirasi masyarakat yakni dari faktor internal maupun eksternal, berbagai realitas inilah yang menjadi dasar dari penelitian ini.

\section{Perumusan Masalah}

1. Bagaimanakah peran anggota DPD dari Provinsi DKI Jakarta Periode 2014-2019 dalam rangka menyerap aspirasi warga daerah?
2. Apa saja faktor pendukung anggota DPD dari Provinsi DKI Jakarta Periode 2014- 2019 dalam menyerap aspirasi warga daerah?

3. Apa saja faktor penghambat anggota DPD dari Provinsi DKI Jakarta Periode 2014- 2019 dalam menyerap aspirasi warga daerah?

\section{Maksud dan Tujuan Penelitian}

1. Untuk memahami peran dan fungsi anggota DPD dari Provinsi DKI Jakarta Periode 2014-2019 dalam proses penyerapan aspirasi warga DKI Jakarta.

2. Mengetahui fakta-fakta pendukung dari anggota DPD dari Provinsi DKI Jakarta Periode 2014-2019 dalam menjalankan proses serap aspirasi masyarakat DKI Jakarta.

3. Mengetahui fakta-fakta penghambat dari anggota DPD dari Provinsi DKI Jakarta Periode 2014-2019 dalam menjalankan proses serap aspirasi masyarakat DKI Jakarta.

\section{Waktu dan Tempat Penelitian}

Bahan penelitian dan/atau obyek penelitian ini adalah peran anggota DPD dari Provinsi DKI Jakarta, dengan unit analisisnya adalah penyerapan aspirasi warga daerah DKI Jakarta. Periode Anggota-anggota DPD dari Provinsi DKI Jakarta yang menjadi kajian adalah Periode Jabatan 2014-2019 lalu, pemilihan masa jabatan ini didasari oleh adanya dinamika peningkatan kewenangan DPD berdasarkan putusan Mahkamah Konstitusi (MK). Berdasarkan obyek penelitian ini juga menjelaskan bahwa waktu dan tempat penelitian dilakukan di DKI Jakarta dengan lima wilayah kota administratifnya. Peran Anggota DPD dari Provinsi DKI Jakarta dengan mengkaji lima wilayah kota administratif yang tentunya membutuhkan peran dari para anggota DPD Provinsi DKI Jakarta sebagai representasi dari wakil mereka di parlemen untuk menyerap aspirasi dan menyuarakan suara daerah pada level nasional. Dengan memahami dari obyek penelitian, unit analisis, dan lokasi penelitian diharapkan akan menghasilkan temuan penelitian untuk menjelaskan 
rumusan permasalahan penelitian yang diajukan dalam penelitian ini.

\section{METODE PENELITIAN}

Desain penelitian ini dirancang menggunakan metode analisis kualitatif. Penelitian Kualitatif dimaksudkan bahwa riset bersifat deskriptif dan cenderung menggunakan analisis. Riset kualitatif bertujuan untuk menjelaskan fenomena dengan sedalam-dalamnya melalui pengumpulan data sedalam-dalamnya (Krisyantono, 2006). Penelitian kualitatif ini menekankan pada kedalaman data yang didapatkan oleh peneliti, sehingga semakin dalam dan mendetail data yang didapatkan, maka semakin baik kualitas dari penelitian kualitatif ini.

Dalam melakukan pengumpulan data pada penelitian ini, penulis menggunakan teknik pengumpulan data dengan metode wawancara. Wawancara bertujuan tidak hanya menangkap/memperoleh pemahaman/ide, tetapi juga menangkap/memperoleh respons bersifat perasaan, pengalaman, emosi, yang dimiliki oleh informan yang bersangkutan (W. Gulo, 2003: 119). Wawancara dilakukan oleh peneliti terhadap informan, dengan perincian informan terbagi menjadi tiga kategori yakni: informan utama dari perwakilan anggota DPD Provinsi DKI Jakarta masa Jabatan 20142019 yakni Fahira Fahmi Idris dan Abdul Azis Khafia. Informan kunci adalah Kepala Kantor DPD Provinsi DKI Jakarta Rahmat Hollyson, juga dari kalangan politisi yang memiliki hubungan kerja dengan anggota DPD dari Provinsi DKI Jakarta seperti Anggota DPR Fraksi Partai Demokrasi Indonesia Perjuangan (PDI Perjuangan) Masinton Pasaribu dan Anggota DPRD DKI Jakarta dari Fraksi PDI Perjuangan Panji Virgianto, dan beberapa warga DKI Jakarta. Sedangkan informan tambahan adalah dari akademisi yakni Faisyal Chaniago Dosen Fakultas Ilmu Sosial dan Ilmu Politik (FISIP) Universitas Bung Karno, dari pengamat parlemen adalah I Made Leo Wiratma Direktur Eksekutif dari Forum Masyarakat Peduli Parlemen Indonesia (Formappi). Sehingga demikian, berdasarkan desain penelitian yang dilakukan akan dapat memperoleh gambaran tentang Peran Anggota DPD dari Provinsi DKI Jakarta masa jabatan 2014-2019 dalam melakukan penyerapan aspirasi warga DKI Jakarta.

\section{HASIL PENELITIAN DAN PEMBAHASAN}

\section{Peran Anggota DPD asal Provinsi DKI Jakarta dalam Penyerapan Aspirasi Warga DKI Jakarta}

Kehadiran DPD bertujuan mengakomodasikan kepentingan daerah secara efektif dan adil melalui pembuatan keputusan politik yang bersifat nasional dan untuk memberdayakan potensi daerah, sehingga dibutuhkan sebuah lembaga yang mempunyai kewenangankewenangan tertentu. Pendapat ini disampaikan oleh Saafroedin Bahar bahwa dihadirkannya DPD adalah untuk menjaga integrasi bangsa yang tentunya memerlukan suatu lembaga yang dapat memberikan masukan, pertimbangan dan bahkan pengawasan terbatas, inilah dasar kehadiran DPD (Saafroedin Bahar dan A.B. Tangadililing, 1999: 59).

Peran yang dijalankan oleh anggota legislator tak bisa dilepaskan dengan kewajiban melakukan penyerapan aspirasi dari masyarakat, warga di daerah pemilihan, dan warga negara Indonesia. Salah satu kegiatan anggota DPD yaitu menyerap, menghimpun, menampung dan menindaklanjuti aspirasi masyarakat dan daerah yang berada dalam ruang lingkup tugas dan wewenang DPD.

Penyerapan aspirasi daerah dilakukan dalam dua bentuk yaitu secara langsung dan tidak langsung. Bentuk penyerapan aspirasi oleh Anggota DPD dari Provinsi DKI Jakarta periode 2014-2019 diakui oleh legislator Fahira Fahmi Idris adalah sangat beragam diantaranya langsung turun ke warga melakukan tatap muka, berdiskusi, melihat langsung persoalan di lapangan, dan juga menggunakan teknologi informasi terutama lewat media sosial (Wawancara, Fahira Idris). Sedangkan, pada saat anggota melakukan kunjungan kerja dan kegiatan di daerah yang diwakilinya, Sekretariat Jenderal berkoordinasi dengan Sekretariat 
Daerah dan Sekretariat DPRD dalam menerima dan menyalurkan aspirasi masyarakat dan daerah kepada anggota.

Serap aspirasi dilakukan oleh legislator DPD dengan juga menyusun laporan hasil kunjungan kerja dalam bentuk resume aspirasi masyarakat yang telah dipisahkan berdasarkan persoalan masing-masing dan melakukan identifikasi persoalan-persoalan tersebut. Sehingga menjadi jelas dan spesifik merujuk terhadap pemilihan atau kategorisasi berdasarkan tugas, kewenangan dari lembaga legislatif dan/atau eksekutif seperti: mana persoalan yang menjadi kewenangan DPD sendiri, persoalan yang menjadi kewenangan DPRD dan Pemerintah Daerah Provinsi, persoalan yang menjadi kewenangan DPRD kabupaten/kota, atau Pemerintah Daerah kabupaten/kota, lalu persoalan yang di luar kewenangan DPD; selanjutnya disampaikan melalui mekanisme rapat kerja di daerah yang didasarkan atas skala prioritas persoalan.

Langkah berikutnya adalah persoalan yang menjadi kewenangan DPD kemudian dibawa ke Pusat untuk disusun bersama-sama anggota DPD dari provinsi masing-masing dan dipilah berdasarkan wilayah kerja Panitia Ad Hoc (PAH) untuk di paripurna-kan. Laporan yang disampaikan pada paripurna setiap awal masa sidang, kemudian disalurkan kepada PAH berdasarkan wilayah kerja masingmasing untuk dibahas bersama dengan pemerintah, dalam hal ini menteri terkait. Sementara itu, terkait dengan masukan dari berbagai kalangan masyarakat mengenai peran ideal DPD ke depan dan peningkatan peran DPD dalam menjembatani hubungan antara Pemerintah Pusat dan Daerah yang konstruktif dan sinergis, maka Kelompok DPD di MPR akan menyampaikan masukan tersebut kepada Pimpinan Majelis Permusyawaratan Rakyat (MPR) RI untuk dapat diproses lebih lanjut (Wawancara, Fahira Idris).

Penyerapan aspirasi warga Jakarta yang diperjuangkan DPD menurut Fahira Idris adalah aspirasi yang tidak hanya dari lapisan warga Jakarta, tetapi juga aspirasi yang menjadi kebutuhan kota Jakarta secara komperehensif. Karena kewenangan DPD hanya boleh mengusulkan dan membahas RUU yang hanya terkait kepentingan daerah, maka yang coba diperjuangkan adalah mengusulkan sebuah regulasi sebagai solusi bagi persoalan utama Jakarta yang juga tentunya menjadi persoalan warga.

Ada beberapa isu yang masih harus diselesaikan dan dalam prosesnya harus diperjuangkan di tingkat nasional atau terkait dengan pemerintah pusat. Salah satunya yang diperjuangkan oleh Fahira Idris adalah persoalan air dan pengelolaan sungai yang nanti ujungnya ke persoalan banjir di Jakarta. Jadi, tiga belas sungai besar yang ada di Jakarta yang menjadi salah satu penyebab banjir, namun kewenangan pengelolaannya ada di Pemerintah Pusat melalui Kementerian Pekerjaan Umum dan Perumahan Rakyat lewat Balai Besar Wilayah Sungai Ciliwung-Cisadane. Artinya, Pemerintah Provinsi (Pemprov) DKI Jakarta tidak bisa bekerja sendiri untuk mengatasi dan menghentikan banjir di Jakarta. Selama kondisi tiga belas sungai yang melintasi Jakarta buruk, maka selama itu juga Jakarta akan banjir.

Selama kerusakan di wilayah hulu Sungai Ciliwung dan Cisadane tidak diatasi, maka ketika hujan, air akan langsung meluncur ke kawasan di hilir, sehingga menyebabkan semakin buruknya banjir di Jakarta. Oleh karena itu, harus ada terobosan. Semestinya dipahami persoalan ini bukan hanya lintas wilayah, tetapi juga lintas kementerian dan lembaga, perlu ada sebuah regulasi yang tegas dan memberi kewenangan Jakarta agar bisa berkoordinasi dengan kabupaten dan kota, agar Jakarta bebas banjir. Perlunya sebuah UU yang memberikan kewenangan lebih besar kepada Pemprov DKI untuk melakukan koordinasi dengan daerah sekitarnya untuk mengatasi bencana banjir. Lewat RUU ini juga, Pemprov DKI Jakarta diberi wewenang lebih besar untuk mengelola tiga belas sungai besar di Jakarta, (Wawancara, Fahira Idris).

Nantinya RUU ini juga mengamanatkan kepada Presiden untuk membuat badan yang khusus untuk 
mengurusi koordinasi antar wilayah Jakarta, Bogor, Depok, Tangerang dan Bekasi (Jabodetabek) dan sekitarnya. Badan ini bertanggungjawab langsung kepada presiden dan diberi kewenangan untuk membuat kebijakan dan tindakan serta melakukan koordinasi dengan daerah sekitar Jakarta serta dengan kementerian terkait untuk mengatasi bencana banjir. Koordinatornya bisa menteri yang ditunjuk Presiden atau salah satu gubernur yang wilayahnya masuk Jabodetabek. Bisa Gubernur Jakarta, Jawa Barat, atau Banten. Badan khusus ini dibutuhkan agar tercipta penguatan koordinasi untuk penataan tata ruang untuk Jakarta dan daerah sekitarnya. Jadi tidak hanya soal sungai dan banjir, tetapi RUU ini juga sebagai solusi mengatasi persoalan transportasi dan kemacetan di Jakarta yang juga tidak bisa dilepaskan dari daerah di sekitar Jakarta. Jadi Jakarta dan daerah sekitarnya bisa sama-sama tumbuh, bebas banjir, punya infrastruktur yang mantap serta jaringan transportasinya lebih baik. Regulasi yang mengatur hal-hal seperti inilah yang akan saya perjuangkan, (Wawancara, Fahira Idris).

Sementara Abdul Azis Khafia mengungkapkan mengenai aspirasi warga DKI Jakarta yang diserapnya di antaranya bahwa aspirasi yang banyak masuk adalah terkait dengan sengketa pertanahan seperti sengketa antar perorangan, sengketa pribadi dengan perusahaan, sengketa pribadi dengan pemerintah daerah, sengketa pribadi dengan pemerintah pusat, bahkan ada juga pribadi dengan lembaga negara dalam hal ini Tentara Nasional Indonesia (TNI); jadi permasalahan tanah di Jakarta yang sampai saat ini masih sangat kompleks permasalahannya. Selain sengketa, masalah duplikasi kepemilikan sertifikat tanah ganda di Jakarta, salah satu aspirasi yang sering banyak masuk seperti di Cidodol, Kebayoran Lama, Jakarta Selatan, itu terkait tanah yang duplikasi.

Aspirasi lain selain tanah yang sering masuk di Komite I juga terkait masalah keamanan dan ketertiban seperti masyarakat merasa terganggu dengan adanya beberapa kejadian gangguan keamanan dan ketertiban juga disampaikan kepada anggota DPD dari DKI Jakarta. Di samping itu, ada pula keluhan tentang kebijakan-kebijakan pemerintah daerah yang merugikan masyarakat. Sementara di Komite III, yang paling banyak masuk aspirasi dari masyarakat terkait mengenai guru honorer, mulai dari regulasinya, honornya, dan juga statusnya. Begitu juga mengenai Calon Pegawai Negeri Sipil (CPNS). Aspirasi lain yang masuk, misal terkait pelaksanaan ibadah haji dan umroh (Wawancara, Abdul Azis Khafia).

Lembaga DPD dalam alat kelengkapannya juga didukung oleh adanya komite-komite yang membagi pengelompokan tugas dalam penyerapan aspirasi. Menurut Azis, DPD juga menjadi salah satu alamat untuk menyampaikan aspirasi warga Jakarta yang sedemikian banyak, sebab itulah ada pengkavlingan untuk memudahkan penyerapan aspirasi, seperti ada pembagian komite di DPD. Rincian komite tersebut: Komite I yang menangani pemerintahan, politik, hukum dan hak asasi manusia (HAM) dan seterusnya; Komite II yang menangani sumber daya air, mineral, listrik, dan sebagainya; Komite III tentang pendidikan, kebudayaan, agama, dan sebagainya; dan Komite IV terkait dengan masalah Anggaran Pendapatan dan Belanja Negara (APBN), keuangan negara berupa pajak dan lsebagainya(Wawancara, Abdul Azis Khafia).

Sayangnya, aspirasi yang diperjuangkan para anggota DPD seakan belum dapat dijadikan antara harapan dan keberhasilan dimasa yang akan datang, karena hingga saat ini masih belum terlihat atau belum tersosialisasi dengan baik dalam penyerapan aspirasi daerah.

$\mathrm{Hal}$ ini sejalan dengan yang dinyatakan oleh I Made Leo Wiratma, menurutnya, anggota DPD itu sebetulnya harusnya rajin turun ke daerah pemilihan mereka masing-masing, sehingga dengan turun, mereka bisa melihat situasi dan kondisi daerahnya mengenai apa yang perlu dibenahi dan sebagainya. Sebab, jika tidak turun akan susah untuk mengetahui persoalan-persolan yang ada di DKI Jakarta (Wawancara, I Made Leo Wiratma). 
Problematika terhadap kinerja legislator DPD dalam penyerapan aspirasi adalah jika anggota DPD provinsi DKI Jakarta dilihat berdasarkan geografis wilayahnya, maka jaraknya sangat dekat dan mudah untuk ditemui warganya. Meski begitu, kita tidak bisa mendeteksi, apa saja hasil kunjungan kerja mereka ke daerah-daerah itu. Sebab, jika dibandingkan dengan DPR, bahwa DPR mempunyai suatu kewajiban kalau mereka kunjungan kerja harus membuat laporan, sedangkan DPD meski membuat semacam laporan hasil kunjungan kerja mereka, tetapi tidak seperti DPR ada yang namanya fraksi, hal mana hasil kunjungan mereka dilaporkan ke fraksi dan fraksi melaporkan ke sidang paripurna. Sedangkan, DPD berbeda, tidak ada fraksi, hanya mereka yang sama-sama wakil dari DKI Jakarta, dengan anggota empat orang. Secara subjektif ini sangat tergantung kepentingan legislator pribadi maupun bersama, kita sebagai publik tidak bisa mendeteksi apa saja hasil-hasil kerja mereka, apakah mereka sudah betul-betul berperan dalam menyerap aspirasi itu, apakah mereka turun melakukan penyerapan aspirasi, andaikan jika anggota DPD dari DKI Jakarta telah melakukan penyerapan aspirasi maka kemana mereka membawa aspirasi itu dan sejauhmana mereka memperjuangkannya di DPD dalam proses legislasi, inilah yang menjadi sorotan publik dalam mengkritisi peran dan kinerja DPD (Wawancara, I Made Leo Wiratma).

Berdasarkan pandangan diatas, penulis melihat bahwa permasalahan peran Anggota DPD dari Provinsi DKI Jakarta dalam penyerapan aspirasi adalah terkait belum tersosialisasi dengan baik hasil kerja dari para anggota DPD tersebut, terlebih mengenai peran dan fungsi lembaga DPD ini pula belum tersosialisasi dengan baik. Padahal, peran anggota DPD dari Provinsi DKI Jakarta berdasarkan hasil penelitian ini dapat dikatakan sudah melakukan peran dan fungsinya sesuai undang-undang.

DPD ini merupakan lembaga negara yang terhitung secara periodik memang masih baru, lahir pasca reformasi yaitu tahun 1999. Sebenarnya DPD, diharapkan sebagai penyeimbang atau check and balance dalam sistem dua kamar di parlemen yakni antara DPR dengan DPD, tetapi perkembangannya dari tahun ke tahun belum terlalu signifikan langkah memperkuat peran DPD. Lembaga DPD masih bersifat soft bikameral (Wawancara, Faisyal Chaniago). Hal ini dikarenakan aturan main dalam hal ini UUD 1945 hasil amanden sebagai payung hukum eksistensi DPD memang masih dalam memposisikan DPD hanya pada tataran yang bukan setara maupun seimbang dengan DPR. Sejak DPD berdiri sampai dengan periode 2014-2019 bahwa posisi dan kewenangan DPD, peran dan fungsi DPD masih sebatas merancang, mengusulkan UU, melakukan pengawasan terhadap UU di samping tugas-tugas lainnya. Padahal yang diharapkan dari berbagai macam pihak bahwa DPD juga memiliki kewenangan dalam rangka menetapkan UU sehingga UU yang dimunculkan itu bukan hanya menjadi kewenangan DPR tetapi juga DPD diberikan ruang.

Jika melihat perkembangan DPD berdasarkan putusan Mahkamah Konstitusi (MK) misalnya, Nomor 79/PUU-XII/2014, bahwa dalam proses legislasi DPD sudah mulai menguat, hal mana DPD berwenang menyusun Program Legislasi Nasional (Prolegnas), mengajukan RUU dan ikut serta dalam proses pembahasan RUU secara tripartit DPR bersama Pemerintah dan DPD, bahkan DPD sendiri saat ini telah memiliki wewenang baru, yakni pengawasan dan evaluasi terhadap peraturan daerah (Perda) seperti diatur dalam UU MPR, DPR, DPD, dan DPRD (UU MD3) tahun 2018 (Efriza, 2021: 19).

Menyikapi kewenangan DPD yang dapat melakukan pengawalan dan evaluasi atas peraturan-peraturan daerah, ini menunjukkan adanya kontribusi DPD nanti dalam rangka bagaimana pemerintah daerah memunculkan produk-produk hukum dalam hal ini Perda. Bagi Fahira, saya pikir itu perkembangannya dari posisi DPD yang ditahun ke tiga ini perubahan yang signifikan baru sebatas dalam keputusan MK, tetapi selebihnya kewenangannya masih sama dengan 
pertama kali DPD dimunculkan dalam konstitusi (Wawancara Fahira Idris).

Dalam pandangan penulis terhadap Peran DPD dari Provinsi DKI Jakarta dalam penyerapan aspirasi warga DKI Jakarta bahwa masyarakat pasca pemilu telah menyerahkan kewenangannya untuk diwakilkan oleh DPD, sehingga DPD diharapkan membawa aspirasi daerahnya kepada tingkat nasional. Konsep DPD dalam menyerap aspirasi di daerah perlu dipahami bahwa berbeda dengan DPRD DKI Jakarta. Sebab, aspirasi-aspirasi Warga Jakarta yang dibawa oleh DPD juga semestinya turut berimbuhan dengan aspirasi-aspirasi daerah lainnya dan persoalan ini harus menjadi suatu hal yang terkait dengan daerah secara keseluruhan, jadi tidak bisa selalu digambarkan sebagai ini aspirasi suara daerah $\mathrm{A}$, suara daerah $B$, atau suara daerah $C$ dan semacamnya, tetapi menjadi suara daerah untuk di bawa ke level nasional.

Persoalan dari penyerapan aspirasi ini dalam proses menuju pembuatan keputusan adalah seberapa besar aspirasi ini bisa terlihat, diperjuangkan bahkan dijelaskan sebagai aspirasi DPD. Sebab umumnya, DPD ketika menyerap aspirasi dan membawa aspirasi cenderung sama seperti DPR RI, bahkan dalam penyerapan aspirasi bahwa sampai di level pembuatan kebijakan antar kedua lembaga legislatif dan perjuangan aspirasi untuk menuju produk legislasi, ternyata tidak terlihat jelas perbedaannya antara kedua lembaga tersebut. Apalagi nyatanya, kinerja DPD tetap membutuhkan peran dari DPR bahkan malah diserahkan kepada DPR dalam proses pengambilan keputusannya.

Persoalan dari penyerapan aspirasi yang dilakukan oleh DPD ini dan juga pemahaman terhadap institusi DPD, ternyata juga belum dirasakan oleh warga DKI Jakarta. Kinerja DPD belum terlihat dan berdampaknya secara langsung, jadi peran anggota DPD provinsi DKI ini belum di rasakan oleh warga Jakarta, bahkan lembaga legislatif DPD tak begitu dikenal (Wawancara, Fachran Caesar dan Fatuhul Aulad).

Jadi, bagi penulis bahwa Anggota DPD utamanya Provinsi DKI Jakarta, kinerja dan perannya secara langsung saat ini belum dapat dirasakan oleh masyarakat DKI Jakarta. Oleh sebab itu, perlu dilakukan pembenahan secara institusi, dan juga anggota DPD perlu lebih meningkatkan kinerjanya dalam melakukan penyerapan aspirasi warga DKI Jakarta, serta lebih giat menjelaskan sosialisasi kinerja para anggota DPD kepada masyarakat DKI Jakarta.

\section{Faktor Pendukung Peran Penyerapan Aspirasi Anggota DPD Provinsi DKI Jakarta}

DPD saat ini dapat dikategorikan memasuki usia remajanya, tak dimungkiri peran DPD telah mengalami proses evolusi atas fungsi legislasi DPD, juga dalam upaya agregasi dan artikulasi kepentingan. Sudah semestinya, meski dengan kewenangan DPD yang masih "kecil" tersebut, anggota DPD harus berani "jungkir balik" memperjuangkan aspirasi rakyat.

Sebab, legislator DPD terpilih mengemban amanat yang telah dititipkan rakyat melalui keterpilihannya di Pemilihan Umum Legislatif 2014 lalu. Harus diakui saat ini, faktor pendukung anggota DPD telah semakin beragam seperti DPD berhak dalam memantau regulasi dan mengevaluasi Perda, ini menunjukkan DPD memperoleh celah untuk anggota DPD melakukan pengawasan kepada daerah khususnya pengolahan Perda.

Faktor Pendukung lainnya adalah Fahira Idris pun menyatakan bahwa saat ini untuk DKI Jakarta sudah didefinitifkan kantor perwakilan DPD provinsi DKI Jakarta, sehingga dapat menjadi sebagai penyambung lidah antara anggota dengan pemerintah daerah (Wawancara, Fahira Idris). Kantor perwakilan DPD yang sudah definitif ini juga dapat membantu kinerja anggota dalam sosialiasi kegiatan para anggota DPD dari Provinsi DKI Jakarta dan dengan adanya kantor perwakilan menunjukkan legislator DPD DKI Jakarta lebih mudah dijangkau masyarakat untuk menyampaikan aspirasinya selain dengan mendatangi langsung di gedung DPD di Senayan (Wawancara, Rahmat Hollyson). 


\section{Faktor Penghambat Peran Penyerapan Aspirasi Anggota DPD Provinsi DKI Jakarta}

Kewenangan DPD dalam konstitusi tak bisa dinafikkan masih dianggap sebagai faktor penghambat dalam kinerja DPD. Lembaga DPD yang semestinya sebagai Senat dalam Sistem Dua Kamar malah dianggap saat ini DPD seperti layaknya LSM plat merah. Secara level nasional dalam konstitusinya DPD seperti LSM plat merah, karena keputusan ada di tingkat DPR, sehingga tidak jelas perjuangan aspirasi DPD sebab dilanjutkan aspirasi ini oleh DPR (Efriza, 2021). Posisi DPD dalam sistem bikameral di Indonesia belum ditempatkan sebagaimana mestinya, inilah keluhan dari Anggota DPD Fahira Idris. Ia menganggap bahwa kewenangan DPD saat ini belum sepenuhnya mampu memperkuat sistem bikameral. Fahira juga menganggap bahwa oleh konstitusi kewenangan DPD “dibonsai," sebab jika merujuk negara lain yang menganut sistem bikameral, DPD atau disebut Senat, semestinya diberi kewenangan yang besar untuk mengimbangi peran dan posisi DPR. Semua itu bertujuan agar mekanisme checks and balances dapat berjalan relatif seimbang antara DPR dan DPD. Setidaknya, DPD diberi kewenangan meneliti ulang setiap RUU yang diajukan DPR, diberi hak yang sama dalam mengajukan RUU, dan ikut mengawasi pemerintahan (Wawancara Fahira Idris).

Sehingga bagi Fahira, meski begitu, yang menghambat sebenarnya tidak ada selama kita sebagai Anggota DPD mau dan berani melakukan terobosan di tengah keterbatasan kewenangan. Kewenangan yang terbatas membuat anggota DPD harus "jungkir balik" memperjuangkan aspirasi rakyat. Masyarakat yang menitipkan aspirasi memahaminya bahwa DPD sebagai wakil rakyat yang memiliki kewenangan besar seperti DPR, sehingga dapat mengawal aspirasi daerah hingga menjadi sebuah kebijakan. Padahal kenyataannya, kewenangan DPD "dibonsai," tetapi kita tetap harus semangat melakukan berbagai terobosan di tengah keterbatasan wewenang (Wawancara, Fahira Idris).

Kendala-kendala yang dihadapi untuk meningkatkan peran anggota DPD utamanya dari provinsi DKI Jakarta yang menjabat pada periode 2014-2019 dalam rangka menyerap aspirasi daerah, berdasarkan temuan di lapangan meliputi faktor internal dan faktor eksternal. Salah satu yang menjadi faktor internal adalah belum terjalinnya komunikasi kerja yang baik antara lembaga-lembaga legislatif, misal dalam hubungan antara DPD dengan DPRD DKI Jakarta. Seperti yang dinyatakan oleh Anggota DPRD DKI Jakarta dari PDI Perjuangan, Panji Virgianto, bahwa sampai saat ini anggota DPD belum pernah berkodinasi dengan DPRD DKI Jakarta. Semestinya dilakukan rapat kordinasi, harus ada kebijakan bersama yang dihasilkan. Misal saja, menyoroti departemen agama bahwa peraturan yang belaku adalah secara nasional, padahal tak serta-merta dapat berlaku secara seluruh Indonesia, sebab misalnya karena melihat kondisi daerah Jakarta, karena kemampuan daerah masing-masing dan melihat kekhususan daerah DKI Jakarta dengan daerah lain berbeda (Wawancara, Panji Virgianto).

Hal senada juga dinyatakan oleh Anggota DPR dari Fraksi PDI Perjuangan Masinton Pasaribu daerah pemilihan Jakarta II, bahwa selama ini tidak terjadi kordinasi terkait dengan fungsi-fungsi pengawasan di daerah khususnya di daerah pemilihan. Fungsi kordinasi antara DPD dengan DPR, maupun DPD dan DPRD juga minim. Sehingga fenomena ini tak hanya terjadi di Jakarta tetapi di provinsi lain juga mengalami hal yang sama, berjalan sendiri-sendiri antar institusi-institusi parlemen. Sehingga belum terlihat manfaat nyata dari DPD (Wawancara, Masinton Pasaribu).

Catatan lain, dari Masinton Pasaribu adalah DPD harus lebih intensif dan efektif, optimal dalam melakukan fungsifungsi seperti fungsi pengawasan, pelayanan publik di daerah-daerah daripada ingin penduplikasi fungsi DPR. Sehingga, DPD lebih baik berpikir fungsi pengawasan dan penguatan publik di 
daerah bersama pemerintah daerah (Wawancara, Masinton Pasaribu).

Meski DPD hadir dengan kondisi terbatas bukan sebagai cek and balance, tetapi lebih kepada semangat mewujudkan bikameral, hal mana DPD dianggap dalam kewenangan terbatas daripada tidak diberi kewenangan sama sekali sehingga DPD hanya dapat memberi masukan. Bahkan, kewenangan DPD juga sempat dalam aturan UU semakin menyusut, tetapi berhasil menguat kembali berdasarkan berbagai keputusan dari MK. Meski begitu dalam perkembangannya, bahwa umumnya DPR dan DPD saat ini, sama saja berasal dari partai, tak ada pembeda jelas antara DPD dan DPR dalam segi keterwakilannya. Bahkan, faktanya anggota DPD banyak yang berasal dari elit partai yang sudah tak aktif lagi di kepengurusan partai maupun untuk dicalonkan kembali sebagai legislator DPR, sehingga DPD tak lebih sebagai buangan politisi tua dari DPR agar tetap eksis.

Jika diamati lebih mendalam bahwa dalam proses legislasi belum terlihat jelas aspirasi antara lembaga-lembaga legislatif yakni DPR dan DPD. Berbagai aturan yang diatur oleh konstitusi dan peraturan perundang-undangan lainnya menjelaskan bahwa secara level nasional dalam konstitusinya DPD seperti LSM plat merah, karena keputusan ada di DPR. Sehingga tidak jelas antara mana aspirasi DPD dan mana aspirasi DPR, apalagi dalam proses akhir berada di tangan DPR, semakin menunjukkan aspirasi DPD seperti sekadar menguap di ruang-ruang Gedung Senayan.

Namun, faktor penghambat juga dapat dianggap sebagai faktor pendukung. Sebab, berkaca kepada pembentukan DPD itu adalah proses yang sangat rumit, DPD hadir memang mau tidak mau kehadirannya dengan kondisi yang terbatas, karena saat itu masih ada persepsi hadirnya DPD itu bukan sebagai check and balance yang di dalam tubuh parlemen, tetapi lebih kepada semangatnya semata. Namun, semangat itu pula tetap menjadi kekhawatiran, semangat adanya check and balance, karena kekhawatiran itu maka akhirnya DPD dianggap lebih baik dengan kewenangan yang terbatas daripada tidak ada sama sekali, itulah yang terjadi dengan DPD . Akhirnya, peranan DPD saat ini tak ubahnya sebagai subordinat DPR. Sehingga wajar akhirnya, saat ini, bahwa DPD dan DPR itu tidak jauh berbeda sama-sama orang partai, DPD kerap diplesetkan sebagai Dewan Perwakilan Daerah dari Partai Politik. Bahkan kenyataannya, DPD itu adalah elit-elit partai yang sudah tidak laku, sudah tidak menarik lagi, tetapi karena sindrom kekuasaan, takut tidak punya kekuasaan lagi, maka ditaruh elite-elite partai itu di DPD, ini adalah berbagai fakta nyata perjalanan DPD di usia remajanya (Efriza: 2021).

Meski kewenangan DPD terbatas, tetapi faktor penghambat janganlah dijadikan pameo atau sebagai batu sandungan atau jadi alasan dalam melaksanakan peran penyerapan aspirasi masyarakat di daerahnya, karena masih banyak yang dapat dilakukan oleh anggota DPD dengan kewenangannya yang terbatas, seperti melakukan advokasi daerah, hal mana anggota DPD berhak meminta penjelasan kepada menteri bahkan presiden sekalipun. Keterbatasan harus tetap menjadi peluang dalam menyerap aspirasi daerah dan melakukan pengawasan terhadap peraturan-peraturan daerah yang dihasilkan oleh pemerintah daerah dan DPRD di daerah-daerah masing-masing (Wawancara, Rahmat Hollyson).

\section{KESIMPULAN}

Pelaksanaan Peran Anggota DPD dari Provinsi DKI Jakarta periode 20142019 dalam menjalankan proses menyerap, menghimpun, menampung dan menindaklanjuti aspirasi daerah dengan secara langsung dan tidak langsung pada implementasinya belumlah maksimal, hal ini dikarenakan adanya faktor penghambat dari faktor internal maupun faktor eksternal.

Meski begitu, faktor pendukung bagi anggota DPD dari Provinsi DKI Jakarta periode 2014-2019 dalam menyerap aspirasi adalah semangat dari para legislator yang telah dipilih secara 
langsung oleh rakyat melalui pemilihan umum, juga adanya keputusan dari MK bahwa DPD dapat melakukan pengawalan dan evaluasi atas peraturan-peraturan daerah, ini menunjukkan diharapkan adanya kontribusi DPD ke depannya dalam rangka bagaimana pemerintah daerah memunculkan produk-produk hukum dalam hal ini peraturan daerah. Faktor pendukung lainnya dalam peran DPD dalam penyerapan aspirasi warga DKI adalah telah didefinitifkan kantor perwakilan DPD provinsi DKI Jakarta, semestinya anggota DPD memahami bahwa warga DKI Jakarta yang bersifat terbuka dalam perkembangan isu dan informasi akan lebih mudah untuk diserap aspirasinya dan DKI Jakarta juga merupakan daerah yang lebih mudah dijangkau dalam rangka penyerapan aspirasi, ini menunjukkan harapan besar patut diberikan terhadap peran anggota DPD dari Provinsi DKI Jakarta ke depannya.

Sedangkan, faktor penghambat yang dihadapi untuk meningkatkan peran anggota DPD dari provinsi DKI Jakarta dalam rangka menyerap aspirasi daerah meliputi faktor internal, seperti kurang aktif dan inovatifnya anggota DPD dalam menyerap aspirasi. Sedangkan dari faktor eksternal adalah kewenangan DPD yang terbatas dalam konstitusi seperti kewenangan untuk turut serta memutuskan undang-undang, berikutnya adalah masih kurangnya sosialisasi kinerja sebagai anggota DPD, dan kurangnya kordinasi antar lembaga legislatif dan pemerintah daerah.

Oleh sebab itu, saran yang diajukan adalah pertama, Anggota DPD dari Provinsi DKI Jakarta harus lebih memaksimalkan kerjanya, kreatif dan inovatif dalam menjalankan perannya dalam menyerap aspirasi daerah dan bekerjasama maupun turut aktif mengkomunikasi dan mensosialisasikan kepada lembaga legislatif lainnya seperti DPR dan DPRD, masyarakat, LSM, dan akademisi, sehingga lebih terlihat peran dan fungsi DPD dalam melakukan proses penyerapan aspirasi bagi warga daerah. Kedua, seharusnya kelanjutan penyerapan aspirasi masyarakat tersebut dapat lebih maksimal didorong dalam proses pembuatan keputusan. Oleh karena itu, di tengah keterbatasan kewenangan DPD juga diperlukan kesadaran masyarakat dan lembaga legislatif lainnya seperti DPR dan DPRD untuk ikut berpartisipasi dalam mendukung penguatan kewenangan DPD, dapat berupa dalam tataran UU maupun melalui Amandemen Kelima UUD 1945. Ketiga, adanya kendala-kendala yang ada sebaiknya tidak dijadikan alasan untuk tidak tercapainya tujuan awal dibentuknya DPD yakni menyuarakan aspirasi masyarakat daerah di tingkat nasional, dan sebaiknya anggota DPD dari provinsi DKI Jakarta dalam melaksanakan peran dan kinerjanya tetap melakukannya dengan maksimal berdasarkan peraturanperaturan yang ada. Oleh karena itu yang lebih penting adalah bagaimana agar kepentingan dan kebutuhan masyarakat bisa terfasilitasi. Keempat, semestinya dengan kewenangan terbatas sekalipun, anggota-anggota DPD tetap optimisme dalam kerja politik sebagai institusi DPD, semangat ini harus tetap dipelihara, malah semestinya lebih bergairah melibatkan publik dalam dinamika hubungan pusat dan daerah.

\section{DAFTAR PUSTAKA}

Bahar, Saafroedin dan Tangadililing, A.B., Integrasi Nasional: Teori, Masalah dan Strategi, Jakarta: Ghalia Indonesia, 1999

Efriza dan Rozi, Syafuan, Parlemen Indonesia, Geliat Volksraad Hingga DPD, Menembus Lorong Waktu, Doeloe, Kini dan Nanti, Bandung: Alfabeta, 2010.

Efriza, Studi Parlemen, Sejarah, Konsep dan Lanskap Politik Indonesia, Setara Press, Malang, 2014.

Efriza, Refleksi Terhadap Eksistensi Dewan Perwakilan Daerah Republik Indonesia (DPD RI), Jurnal Caraka Prabu, Vol. 5, No. 1, Juni 2021, http://ejournal.fisip.unjani.ac.id/ index.php/jurnal-caraka$\mathrm{prabu} /$ article/view/535/226

Gulo, W., Metodologi Penelitian, Jakarta: Grasindo, 2003. 
Loulembah, M. Ichsan, Bikameral Bukan Federal, Artikel DPD dan Perwakilan Politik Daerah Kelompok Politik daerah DPD di MPR RI, Jakarta: DPD RI, 2006.

Kriyantono, Rachmat, Teknik Praktis Riset Komunikasi. Jakarta: Prenada, 2006.

Purnomowati, Reni Dwi, Implementasi Sistem Bikameral dalam Parlemen Indonesia, Jakarta: RajaGrafindo Persada, 2005

Wawancara, Abdul Azis Khafia, Anggota DPD Provinsi DKI Jakarta Periode 2014-2019, di Cidodol, Kebayoran Lama, Jakarta Selatan.

Wawancara, Fachran Caesar, Mahasiswa warga Jakarta Barat, di Palmerah.

Wawancara, Faisyal Chaniago, Dosen Fakultas Ilmu Sosial dan Ilmu Politik (FISIP) Universitas Bung Karno, di Kampus Universitas Bung Karno, Cikini.

Wawancara, Futuhul Aulad, yang bergabung dalam Kelompok Studi
Komputer yang juga warga Jakarta Timur, di Palmerah.

Wawancara, Masinton Pasaribu, Anggota DPR dari Fraksi PDI Perjuangan 2014-2019, pada di Cipulir.

Wawancara, I Made Leo Wiratma, M.Si, Direktur Eksekutif FORMAPPI, di Matraman.

Wawancara, Panji Virgianto, Anggota DPRD DKI Jakarta dari Fraksi PDI Perjuangan 2014-2019, di Manggarai.

Wawancara, Rahmat Hollyson, Kepala Kantor DPD RI Provinsi DKI Jakarta, di Kantor DPD RI Provinsi DKI Jakarta, Gedung NYI Ageng Serang, Kuningan.

Wawancara Tertulis, Fahira Idris, Anggota DPD Provinsi DKI Jakarta Periode 2014-2019, di Senayan.

Sistem Informasi Kegiatan dan Kinerja Anggota DPD DKI Jakarta serta Jaringan Aspirasi Masyarakat DKI Jakarta, https://jakarta.dpd.go.id/public/pos t/detail/dpd-ri 